\title{
Institutional Trust and Corruption: evidence from Latin America
}

\section{Confiança institucional e corrupção: evidências da América Latina}

\author{
Luca Andriani \\ Margarita Maria Escudero Loaiza
}

\begin{abstract}
During decades of political and social change, corruption has become a pervasive and habitual factor of Latin American governments. The literature of political economic of corruption largely debates about the negative impact that inefficient anti-corruption policies have on state accountability. Undoubtedly this work contributes to the literature by providing important supportive evidence on this matter. Using data from the Latinobarómetro collected between 2006 and 2010, this study explores the relationship between citizens' perception of corruption and trust toward public institutions, more commonly called institutional trust. Empirical evidence suggests that citizens' trust increases if they perceive improvements in reducing corruption. These results are robust also to the inclusion of several socio-economic covariates as well as when we replicate the analysis for each institutional trust item separately. Our analysis inevitably connects with the literature of quality of government institutions and makes of the Latin American context the new geopolitical ground for this complex debate.
\end{abstract}

\section{Keywords}

Institutional Trust; Corruption; Social Trust; Latin America; Regression Analysis.

\section{Resumo}

Durante décadas de mudanças políticas e sociais, a corrupção se tornou um fator pervasivo e habitual nos governos latino-americanos. A literatura sobre a economia política da corrupção debate, em grande parte, os impactos negativos que políticas anticorrupçáo ineficientes têm na responsividade do Estado (state accountability). Sem dúvida, este trabalho contribui para a literatura ao oferecer evidências importantes de suporte para esse assunto. Com dados do Latinobarómetro coletados entre 2006 e 2010, este estudo explora a relação entre a percepção dos cidadãos em relação à corrupção e à confiança nas instituiçóes públicas, mais comumente chamada de confiança institucional. Evidências empíricas sugerem que a confiança dos cidadãos cresce se eles percebem melhoras na redução da corrupção. Esses resultados são robustos também para a inclusão de várias covariáveis socioeconômicas, bem como quando replicamos a análise para cada item de confiança institucional separadamente. Nossa análise inevitavelmente estabelece relação com a literatura sobre a qualidade das instituiçóes governamentais e faz do contexto latino-americano o novo terreno geopolítico para esse debate complexo.

\section{Palavras-chave}

Confiança Institucional; Corrupção; Confiança Social; América Latina; Análise de Regressão. 


\section{Introduction}

This work explores the nexus between citizens' perception of corruption and their trust towards public institutions, named here institutional trust, in Latin America.

Latin America is a region that has undergone democratic transitions and reforms throughout the twentieth century. Brazil, Argentina, Uruguay and Chile moved from military regimes to democracies in the 1980's forming part of third wave of democratization (HUNTINGTON, 1991). According to the Washington Consensus, others, such as Argentina and Peru went through crucial economic policy changes to move towards a more regulated open-market (RODRIK, 2006; MARANGOS, 2009; NORTH, 1991). Armed and civil conflicts, high levels of crime and drug-trafficking have also been part of the region's history. Even though, democracy is established in this region, its institutions are weak and not well consolidated (GONZÁLEZ, 2006).

Previous research suggests that the political system and its institutions of authority must be regarded as legitimate by society in order to have consolidated democracies (LIPSET, 1994; CHEIBUB et al., 1996). Furthermore, Norris (1999, p. 205) states, that institutions are the core and "basic pillar of society". Others have also said that institutions are the bridge between citizens and governments, and thus represent basic citizen interests. Consequently, the stability and legitimacy of democratic governments depends on political institutions (LEVI and STOKER, 2000; CITRIN and MUSTE, 1999).

Indeed, trust in public institutions, so called institutional trust, has been argued by most scholars to be of fundamental importance to the establishment, survival and functionality of democratic systems (CHANG and CHU, 2006; HAKVERDIAN and MAYNE, 2012; HETHERINGTON, 1998; EASTON, 1965). This is because citizens' belief in institutions is vital for their legitimation (ANDERSON and TVERDOVA, 2003). As such, over the past two decades there has been an increasing interest in institutional trust, in particular in the field of comparative political science and behavioural economics (DALTON, 2004; NORRIS, 1999; HARDIN apud PHARR and PUTNAM, 2000). It has been suggested that in practice citizens differentiate between different institutions regime. As a result, different institutions are given different levels of trust. Moreover, many have expanded Easton's classification of political system support to allow distinction between support for the community, political actors, support for democracy, institutions etc. (NORRIS 1999; CANACHE; ALLISON, 2005; DALTON, 1999). However, institution effectiveness and correct 
functioning can be greatly affected by the corrosive effect of corruption, producing discontent and loss of citizen confidence and trust (HAKVERDIAN and MAYNE, 2012).

This is particularly the case in Latin America. The complex phenomenon of corruption has been a strong factor affecting citizens' confidence in institutions and the legitimacy of the democratic political system, constraining the pace of development of the region. Chile and Uruguay (SELIGSON, 2006) have the lowest levels of corruption. However, the rest of the region consistently shows relatively high levels of corruption, according to the Corruption Perceptions Index by Transparency International in each year reports ${ }^{1}$. Therefore, in almost the whole region, corruption is part of the day-to-day life of citizens. This endemic corruption affects the performance and proper functioning of political institutions and is reflected in the confidence that individuals place on them.

The literatures explaining citizens' institutional trust often focuses on cultural and institutional factors (NORRIS, 1999; MISHLER and ROSE, 2005).

Institutional trust has been widely studied in relation to well-established democracies, in particular since the 1960s (PHARR and PUTNAM, 2000; NORRIS, 1999). However, the Latin American context has remained unfolded (BOHN, 2013). Therefore, it is important to test the established theories relating to corruption and institutional trust in a comparably new setting. Latin American countries represent a very interesting context of analysis as even though they exhibit distinctive political, economic and institutional trajectories, they have similarities with respect to public institutions and their Civil Law Systems. This is due to the fact that as colony of the Spanish Empire (with the exception of Brazil colonised by Portugal) most of the countries share similar formal institutions and legal systems (BRIERLEY and DAVID, 1985). Furthermore, it is important to examine the state of trust in the region after more than a decade of political and economic changes. Moreover, the region scores high in corruption, with little improvement according to the Corruption Perception Index by International Transparency. Therefore, what makes analysis of this region

\footnotetext{
${ }^{1}$ Transparency International is a non-governmental organization that informs about the state of political corruption in the world. Each year it scores countries on how corrupt their public sectors are through the Corruption Perception Index. Available at: <http://www.transparency.org/>. Accessed on: Apr. 05, 2021.
} 
compelling, is the potential association that the high level of corruption could have on citizen trust in public institutions.

The countries within Latin America are elected democracies, though institutions are still weak and with little structure. The democratic regime and mechanisms are still under constant evolution relying upon the effectiveness of public institutions to make democracy work (CORRALES and PENFOLD-BECERRA, 2011). Where governance is affected by instability, however, pervasive problem of corruption is more likely to flourish. This has a negative impact on the quality of institutions as unable to meet citizens' expectations and needs with the consequence of reducing citizens' institutional trust. This is important to consider because, in countries where corruption is part of day-to-day life, citizens' assessment of political performance could be highly influenced by the pervading culture of corruption (ECKSTEIN, 1988 apud MISHLER and ROSE, 2005). That is to say that, citizens in Latin American countries could have generated some tolerance to the ineffectiveness of governments to tackle corruption and thus become disaffected (MORRIS and KLESNER, 2010). Therefore, it is important to explore whether the perception of corruption affects institutional trust.

Our analysis uses survey data collected from the Latinobarómetro during the period 2006 to 2010 and includes 18 Latin American countries. Institutional trust is a composite variable that includes trust items in five public institutions (government, congress, police, judiciary and political parties). From the same survey data, we also collect the main variable of interest of corruption indicating citizens positive perception of a reduction of corruption in the last two years at the time of the interview.

We conduct a series of linear regression analysis based on Ordinary Least Square Estimations and we consistently find that trust towards public institutions increases among citizens that perceive an improvement in the reduction of corruption. These results are statistically significant and they are robust to the inclusion of several key covariates such as social trust and satisfaction with democracy as well as to the inclusion of different socio-economic and demographic characteristics. We also disentangle the composite variable of institutional trust and we replicate our estimations for each individual trust item. Consistently we find that the nexus institutional trust - perception of corruption remains unaltered as perceived improvements in reduction of corruption seems to be a positive and statistically significant predictor of each individual trust item. 
Our results confirm empirical evidence found in other geopolitical contexts including east Europe and Asian democracies. This outcome clearly emphasises the importance of further and more detailed investigations on institutional transparency within the Latin American region. The remaining paper is structured as follows

The next section will present the existing literature discussing trust and corruption concepts as well as the distinction between the institutional and cultural approach; Section 3 discusses the contextual background; Section 4 presents data and variables, Section 5 presents the empirical results; Section 6 concludes.

\section{Relevant Literature}

Institutional trust is defined as the trust that citizens place in public institutions and it plays a very important role in contemporary democracies (HAKHVERDIAN and MAYNE, 2012). Hetherington (2005) argues that citizens' trust in institutions reflects the perception individuals have of whether a government is generating outcomes in accordance to their expectations. Others have related institutional trust to the confidence that individuals place in political actors and institutions to operate in a manner that will benefit them, or at least in a way that will not cause any harm (HAKHVERDYAN and MAYNE, 2012; LEVI and STOKER, 2000; NEWTON and NORRIS, 2000). For instance, Pharr and Putnam (2000) and Dalton (2004) consider institutional trust as a democratic good itself, important for the health and consolidation of democratic systems. Additionally, trust contributes to the support of democratic ideals (SELIGSON, 2002). Institutional trust has also been related to key political and non-political attitudes, including public policy preferences and compliance with government regulation and civic duty (CHANLEY, RUDOLPH and RAHN, 2000; HETHERINGTON, 2005; LETKI, 2006; apud HAKHVERDIAN and MAYNE, 2012).

According to Thomas Hobbes's idea of the social contract, individuals have renounced, explicitly or tacitly, some of their freedoms in order to allow the authority or government to protect and safeguard their remaining rights. Individuals must perceive authorities as impartial entities that protect their interests in benefit of the whole community (PHARR and PUTNAM, 2000; ROTHSTEIN, 2021). Consequently, democratic institution should be trustworthy. Levi and Stoker (2000) explained that trustworthiness is an attribute that an institution or individual possesses, which reassures others that it/she will not betray their trust. Hence, trustworthy 
institutions should act in a fair and neutral manner taking into account all or the most important interests of the community that they represent (LEVI and STOKER, 2000). Institutions therefore have to respect the duties and principles of democratic institutions and the trust that citizens have placed in them. In this sense, political institutions should be competent (HARDIN apud PHARR and PUTNAM, 2000) and meet citizens' expectations.

Institutional wrongdoing such as engagement of its public officials on corrupt exchanges can undermine citizens' confidence that their interests will be safeguarded (CHANG and CHU, 2006).

Corruption is a historically well-established phenomenon, which in many societies occurs in both the public and private sphere (HODGSON and JIANG, 2007). However, corruption manifests in different ways according to the social and cultural context where the illicit act is produced. As such corruption is difficult to conceptualise. For instance, the exchange of presents between citizens and public officials are a part of Thai culture and social behaviour (PHONGPAICHIT and PIRIYARANGSAN, 2001 apud CHANG and CHU, 2006). Whereas this behaviour would be condemned as corrupt practice in western cultures (KURER, 2005). Corruption as a concept is further complicated by the fact that, due to its social nature, it evolves following new patterns with new malign effects in different societies (CHANG and CHU, 2006). As Bardhan (1997) points out, corruption has always been present in different places and times with different "damaging consequences". This complexity makes corruption hard to understand and measure, and can hinder the success of anti-corruption strategies, especially in developing countries.

Therefore, corruption has been defined in different ways. Kurer (2005, p. 223) suggests, "[...] the evolution of the term has indeed been closely connected to the breaking of public office norms and therefore to public disapproval". While Bardhan (1997, p. 1321) defined corruption as "[...] the use of public office for private gains, where an official (the agent) entrusted with carrying out a task by the public (the principal) engages in some sort of malfeasance for private enrichment which is difficult to monitor for the principal". Nevertheless, all the different definitions of corruption found in the literature share two common factors. First, the mistreatment or abuse of authority by those in charge of a public office or public role. This entails accepting, solicitating or extorting a bribe. Second, corruption is also thought to involve a private advancement. That is to say the corrupt official gains " [...] personal, close family or 
private clique pecuniary" benefits (KURER, 2005, p. 225), or transfers them to groups or parties to which he or she belongs (BARDHAN, 1997 apud TREISMAN, 2000).

To unify these factors, several scholars and international organizations have opted for a loose definition of corruption. Klitgaard (1988) for example gives a simplistic definition: "discretion plus monopoly minus accountability equals corruption” (LAWSON, 2009, TEORELL, 2007 and ANDVIG and FJELDSTAD, 2001 apud PERSSON, ROTHSTEIN and TEORELL, 2013). However, the most common and straightforward definition is "the misuse of public office for private gain" (SANDHOLTZ and KOETZLE, 2000, p. 32 apud ANDERSON and TVERDOVA, 2003; TANZI, 1998; KAUFMAN, 1997; ROSE-ACKERMAN, 1999; Transparency International). This is the definition that will be used throughout the present study

The literature of the revisionists considers that corruption might be beneficial for a country in order to achieve development. For instance, Huntington (1968), famously argued that "[...] the only thing worse than a society with a rigid, over centralized, dishonest bureaucracy is one with a rigid, over centralized honest bureaucracy". In other words, corruption might be functional to the maintenance of the political system as it can "[...] provide immediate, specific, and concrete benefits to groups which might otherwise be thoroughly alienated from society" (HUNTINGTON, 1968 apud CHANG and CHU, 2006). Therefore, corruption operates as a function of distribution and allocation of resources for groups that otherwise would be excluded (BECQUART-LECLERQ, 1989 apud SELIGSON, 2002). For Lien (1986), corruption contributes to the allocation of resources and bribery encourages efficiency "[...] since only the lowest-cost firm can afford the largest bribe in a competitive bidding environment" (apud CHANG and CHU, 2006, p. 260). Moreover, it has been argued that corruption contributes to economic growth (HUNTINGTON, 1968 apud CHANG and CHU, 2006).

In contrast to this literature and aligned with our perspective, modern studies on corruption have shown its detrimental effects. Some scholars have focused on the consequences of corruption, while others have focused on its causes. As a result, there is a considerable extended literature on the negative effect of corruption on economic growth and investment and reduction of capital inflow (MAURO, 1995; TANZI and DAVOODI, 2001; GYIMAH-BREMPONG, 2002; KAUFMANN and WEI, 2000; LAMBSDORFF and CORNELIUS, 2000). These studies suggest that political corruption dismisses the most fundamental aspects of democratic states. Kaufmann 
and Wei (2000) showed that the quality of institutions decline with the level of corruption. Moreover, Gupta, Davoodi and Tiongson (2001) found that countries with a high level of corruption have a child mortality rate. Such countries have also been observed to invest in more military spending and arms procurement (GUPTA, DE MELLO and SHARAN, 2000). Countries with high indices of corruption also reported poor tax collection revenue in relation to their GDP (TANZI and DAVOODI, 1998; FRIEDMAN et al., 2000). Interestingly, bureaucratic countries have reported an association between corruption and the state of entry rules governing new businesses (DJANKOV et al., 2002). Similarly, Lambsdorff and Cornelius (2000) suggest that countries with soft government regulation reported higher level of corruption.

\section{Institutional Trust between Cultural and Institutional Theory}

Institutional trust has been often explained under the lenses of cultural and institutional theories (NORRIS,1999; MISHLER and ROSE, 2005; KAASA and ANDRIANI, 2021). This literature stresses on the perspective that both cultural aspects as well as institutional factors may influence to some degree citizens' view and trust towards public institutions (KAASA and ANDRIANI, 2021).

Cultural theory considers trust as a cultural feature, embedded and transmitted within the society. Institutional trust is a product of individual judgments from citizens towards political institutions. However, this perspective considers social norms, values, common customs and beliefs that are present in any society, as important to the establishment of trust. The basis of trust is thought to be family bonds, face-to-face interaction and sharing of experiences among members of a group. The next level of trust is interpersonal or social trust. Connection between members of a community enhances the levels of trust among them, generating positive attitudes towards strangers (FUKUYAMA, 1995; LEVI, 1997). Hence, the trust in political institutions will be a reflection of interpersonal trust (MISHLER and ROSE, 2005).

To answer the question as to why trust is important for cultural theories, Mishler and Rose (2005) present three points. Firstly, cultural theory assumes a mutual relationship between institutional trust and support for the regime. This way, citizen trust in democratic institutions contributes to enhancing adequate institutional performance, and consequently an increase in citizen support (EASTON, 1965 apud MISHLER and ROSE, 2005). Secondly, trust contributes to the "acceptance of democratic values and ideas". Thirdly, trust helps promote the "quality and quantity 
of political involvement" (NORRIS, 1999; PUTNAM et al., 1993 apud MISHLER and ROSE, 2005, p. 1053). Individuals who are more closely connected tend to participate in political and social activities (FUKUYAMA, 1995; PUTNAM, 2000 apud MISHLER and ROSE, 2005). Furthermore, Trusting people implies a more positive attitudes about society (BREHM and RAHN, 1997). Therefore, societies where citizens trust others reported to have more "civic culture" which manifested in the political support that is essential for an effective democratic system (PUTNAM et al. 1993 apud MISHLER and ROSE, 2005). Moreover, trusting societies are more likely to expend resources in social programmes as well as more active governments and low levels of criminality (USLANER, 2002).

There are a variety of discussions in the literature of the causal link between social and institutional trust. Putnam, Leonardi and Nanetti, (1993) assumes that the relationship between interpersonal and institutional trust is one-directional, where interpersonal trust is conducive to institutional trust. In contrast, others have argued that causal arrows go in both directions. Brehm and Rahn (1997), for example, statistically demonstrate mutual influence between the two, though they find that confidence in public institutions has a stronger impact on interpersonal trust than vice versa. Levi (1996 apud LEVI and STOKER, 2000) identifies a similar linkage, noting how building confidence in governmental institutions has the potential to restore levels of interpersonal trust. Empirical studies tend to confirm this linkage. Rothstein and Stolle (2002, p. 16) expressed "[...] government institutions generate social trust only if citizens consider the political institutions to be trustworthy." Additionally, "[...] societies in which the impartiality of the order institutions (police, judiciary) cannot be guaranteed, which is expressed by lower citizens' confidence in these types of institutions, producing lower generalized trust (and vice versa)" (ROTHSTEIN and STOLLE, 2002, p. 21).

Nevertheless, according to Norris (1999), there is not a significant relationship between interpersonal and institutional trust at the individual level. This means, "[...] socially trusting people are not necessarily politically trusting and vice versa" (NEWTON and NORRIS, 2000 p. 72 apud PHARR and PUTNAM, 2000). It has also been argued that in the modern world, solid social and political context and integration build upon the confidence in institutions rather than confidence among citizens (NORRIS, 1999). Although this conclusion was drawn at the individual level, this relationship seemed to be more robust at the national level. Veenstra (2002) 
supported this argument with findings in Canada where interpersonal trust did not increase institutional trust. Similarly, Blind (2007) states that trustworthy government produces interpersonal trust, rather than the opposite. Norris (1999) argues further that political trust is distributed irregularly regardless of personality and social types, because institutional performance influences everyone unequally. For instance, poor economic growth, government corruption or a lack in tackling crime is spread among the citizens independently of their level of social trust, affecting their satisfaction with government and institutions.

According to the Institutional theory, trust and the support for the democratic regime are generated by the rational response to individual or collective assessment of institutional performance (NORTH, 1991; MISHLER and ROSE, 2001 apud MISHLER and ROSE, 2005). For instance, economic growth, political performance, safeguard of civil liberties, rule of law and the reduction of levels of corruption are commonly related to institutional trust and political support (apud MISHLER and ROSE, 2001; 2005; MAURO, 1995; PUTNAM et al., 1993, KNACK and KEEFER, 1997; WHITELEY and CASEY, 2004 apud BJORNSKOV, 2010). In fact, Hetherington (1998) found that improvements in state-effectiveness, improvement of the economy and congress approval fostered political trust. In this regard, poor performance of government, inefficient and poor services of public institutions, weak and ill-functioning institutions due to corruption can lead to a negative impact on the confidence that citizens have in institutions. In contrast, institutions that show efficiency in these areas will generate more trust (MISHLER and ROSE, 2005).

To analyse Institutional trust, Hakhverdian and Mayne (2012) used Scharpf s (1999) performance criteria for how citizens assess public institution. One is procedural performance, which is related to "input"; the other is policy performance related to "output". Procedural performance refers to the rules and procedures of the whole political system and as such expressions of fairness and equality. On the other hand, policy performance alludes to individual evaluations of the way in which public institutions and actors implement and provide services, and respond to citizen priorities. If these criteria are met, high levels of institutional trust are expected (HAKHVERDIAN and MAYNE, 2012; SCHARPF, 1999). Applying this to this issue of corruption, it has been suggested that corruption hinders the ability of institutions to conduct their procedural performance in an equal manner (DOIG and THEOBALD, 2000). Indeed, it has been said that "Countries in which petty corruption is pervasive must [...] endure disabling low levels of trust in public 
institutions, with all the extremely negative consequences for commitment to collective projects, civic behaviour, level of crime and public order" (SELIGSON, 2002, p. 412).

Nonetheless, citizens' assessment of government and institutions performance is likely to have a high degree of cultural influence (ECKSTEIN, 1988 apud MISHLER and ROSE, 2005). For example, in societies where corruption is widespread, the perception of corruption could be less noticeable or important, than in cultures where corruption is rare (MISHLER and ROSE, 2005). Hence, the impact on institutional trust is going to be less severe in societies where corruption is part of daily life. This could be the case in Latin America, where corruption is relatively diffused (BOHN, 2013). Nevertheless, robust empirical evidence shows a negative relationship between citizens perception of corruption and institutional trust even in contexts with a relatively endemic level of corruption including Asian democracies (CHANG and CHU, 2006) and post-communist countries (KAASA and ANDRIANI, 2021).

\section{The Contextual Background}

Latin America is a region with a long history of corruption, since decolonisation, but especially during the period of the Cold War. The rampant corruption was tolerated during that period by the United States to avoid the potential support of communism by Latin American countries (SELIGSON, 2002). However, the shifted of neoliberal reforms, open trade (RODRIK, SUBRAMANIAN and TREBBI, 2004) and efforts to eradicate the narcotics trade have contributed to the increase of corruption in this region. In particular, in policy spheres, within political parties and judicial institutions (SELIGSON, 2002).

Weyland (1998 apud SELIGSON, 2002) has argued that despite the replacement of dictatorships with democratic systems, corruption was present during the military regimes. Consequently, shifting to a democratic system generated more corruption since there is "an increase in the number of palms that need to be greased" (WEYLAND, 1998 apud SELIGSON, 2002). Moreover, new liberal reforms open new areas of the market, increasing the opportunities for bribery. Even after years of democratization in Latin America, in 2001 The Economist stated that "Certainly, privatisations have too often been tainted by corruption, and contracts padded, and bribery and influence-peddling remain common. The drugs trade and the need to 
finance political campaigns have both played a role in spreading corruption" (WANTED..., 2001).

The Transparency International Corruption Perception Index has also showed continuous evidence of high levels of corruption in Latin America. Most of the Latin America countries are signatories of the UN and Inter-American Convention against corruption, and The Organization of American States (OAS) convention in this matter. In several anti-corruption organisations platforms such as Transparency International corruption has been associated to a terrible cancer impacting the legitimacy and integrity as well as reducing citizens' trust in democracies. ${ }^{2}$

This is somewhat illustrated by the several high-profile political corruption wrongdoings of former Latin American presidents including Carlos Menem in Argentina and Luis González Macchi, in Paraguay. Furthermore judges, politicians, generals and high-level business people in Peru have been under investigation due to corruption networks in existence during the Alberto Fujimori mandate. Fujimori was sentenced in 2009 for embezzlement though in 2004, Transparency International estimated the amount of money appropriated to be over $\$ 600$ million. In Colombia, national officials embezzled a reported $\$ 27$ million from the education budget (LIMA, 2013).

Using data from the Latinobarómetro during the period 2006-2010, Figure 1 shows the average trend of institutional trust across Latin America. The graph shows a drop in institutional trust between 2006 and 2007 and a subsequent increase from 2007 until 2009, while it remains almost steady during the following year. ${ }^{3}$

González (2006) has counted nine "severe political cris[es]" connected to institutions in Latin America in between 2000 and 2006 (Paraguay 2000, Perú 2000, Venezuela 2003, Bolivia 2003 and 2005, Ecuador 2000 and 2005, and Nicaragua 2005). Corruption is believed to be the underlying cause of these crises, affecting citizens' confidence in public institutions

\footnotetext{
${ }^{2}<$ https://voices.transparency.org/about>. Accessed on 12 June 2018.

${ }^{3}$ The graph was produced in order to visualise the changes of institutional trust. Because the data of the Latinobarómetro is not longitudinal but rather prospective cross section data, a line plot was used instead of the repeated measures ANOVA to examine changes in institutional trust in Latin America during the period 2006 to 2010 . The graph below illustrates mean confidence level at each year with the respective $95 \%$ confidence Interval.
} 
Figure 1 - Institutional Trust in Latin America 2006-2010

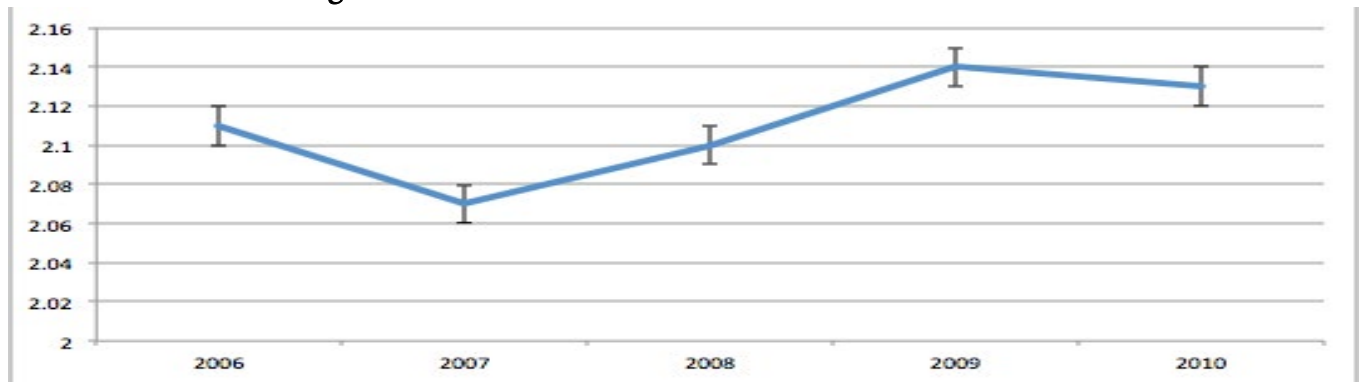

Source: Author's computation from Latinobarómetro Survey 2006-2010.

Looking at the trend of reduction of corruption, still using data from the Latinobarómetro, Figure 2 reports a continued reduction in corruption from 2006 to 2009. Yet, there was a slower decrease from 2009 to 2010.

Figure 2 - Reduction of corruption 2006-2010



Source: Authors' computation from Latinobarómetro Survey 2006-2010.

Therefore, the pattern of institutional trust and corruption in this region for the period of 2006 to 2010 was the same. The exception being the period 2006 to 2007, when despite improvements in the level of corruption, confidence in public institutions slightly dropped. This could have been a product of the turbulent political crisis across the region exposed by González (2006) as mentioned above.

\section{Data and Variables}

This research makes use of the compiled data from the Latinobarómetro for the period 2006-2010, a public opinion survey in 18 Latin American countries on annual basis. Each country is represented by a sample of 6,000 observations for a total of 101,055 observations along the five waves of the survey. 


\section{Measuring Institutional Trust}

We construct a composite variable of institutional based on five distinct composite trust items each of them referring to citizens' trust on a specific public institutions including trust in the government, trust in the police, trust in the congress, trust in the judiciary, and trust in political parties. This composite measurement of institutional trust is aligned with the ones used in the literature (CHANG and CHU, 2006; HAKVERDIAN and MAYNE, 2012). 18 Latin American countries were included (Argentina, Bolivia, Brazil, Colombia, Costa Rica, Chile, Ecuador, El Salvador, Guatemala, Honduras, México, Nicaragua, Panamá, Paraguay, Perú, República Dominicana, Uruguay, Venezuela) for the period of 2006 to 2010 with a sample size of 101,055 observations.

In line with studies of institutional trust (CHANG and CHU, 2006; HAKVERDIAN and MAYNE, 2012), the questions used to measure institutional trust was: "Please look at this card and tell me how much confidence you have in each of the following groups, institutions or persons mentioned on the list: a lot, some, a little or no confidence?." Each item reported values from 1-4, where 1 represented the highest degree of confidence and 4 the lowest. However, the values were changed in the way that 1 represents the lowest and 4 the highest degree of confidence in the respective public institution.

At the country level, the measure of trust was produced by a composite variable of the mean confidence in these five institutions, so that mean confidence was used as the main measure of institutional trust in line with Chang and Chu (2006) and Hakverdian and Mayne (2012).

\section{Measuring Corruption}

The independent variable for corruption is operationalized by the Latinobarómetro question: "How is the progress on reducing corruption in state institutions (2 years) Much, Some, Little, No progress at all”. Each item reported values from $1-4$. The values were rescaling in a way that 1 represents no progress at all and 4 much progress. This allows to interpret the respective regression coefficient in the empirical analysis in a more straightforward way. A positive coefficient will eventually indicate an increase in institutional trust among people that perceive an improvement in the reduction of corruption. 


\section{Measuring Additional Covariates}

Following previous literature, other explanatory factors are considered including interpersonal trust, satisfaction with democracy, socioeconomic status, education, employment, gender, and age (ANDERSON and TVERDOVA, 2003; MISHLER and ROSE, 2001; CHANG and CHU, 2006; SELIGSON, 2002).

In relation to social trust the Latinobarómetro asked respondents "Generally speaking, would you say that you can trust most people, or that you can never be too careful when dealing with others. You can trust most people or you can never be too careful when dealing with others?”.

In order to analyse how individuals assigned their trust in institutions performance the variable of satisfaction with democracy was included (CHANG and CHU, 2006). The corresponding question is: "In general, would you say that you are very satisfied, fairly satisfied, not very satisfied or not at all satisfied with the way democracy works in [nation]. Very satisfied, rather satisfied, Not very satisfied or Not at all satisfied?"

Age was used reported as a categorical variable as follows: 16-25 years, 26-40 years, 41-60 years, and 61 years and above

Socioeconomic status and education were included in line with Seligson (2002). It is reported by the author that higher socioeconomic level and education tend to be more critical as they are more knowledgeable. Gender was also included; according to Chang and Chu (2006) there is a belief that women in Asia are "politically marginalized".

Table 1 shows the variables and describes the composite items and scales. We provide more detailed information about our sample and data across Tables 2 to 4 showing respectively Distribution of Confidence levels for each institutional trust item (Table 2), the descriptive statistics of the variables of corruption (Table 3), and descriptive statistics of the other control variables (Table 4) 
Table 1 - Variables and Values

\begin{tabular}{|c|c|c|c|}
\hline $\begin{array}{l}\text { Dependent } \\
\text { variable } \\
\text { Institutional Trust }\end{array}$ & $\begin{array}{l}\text { Government } \\
\text { Congress/Parliament } \\
\text { Judiciary } \\
\text { Police } \\
\text { Political Parties } \\
\end{array}$ & $\begin{array}{l}1=\text { no confidence at all } \\
2=\text { little confidence } \\
3=\text { some confidence } \\
4=\text { A lot of confidence }\end{array}$ & $\begin{array}{l}1=\text { no confidence at all } \\
2=\text { little confidence } \\
3=\text { some confidence } \\
4=\text { A lot of confidence }\end{array}$ \\
\hline Institutional Trust & Confidence (Mean) & & \\
\hline \multirow[t]{3}{*}{$\begin{array}{l}\text { Independent } \\
\text { Variable } \\
\text { Corruption } \\
\end{array}$} & $\begin{array}{l}\text { Progress on reducing corruption in } \\
\text { state institutions ( } 2 \text { years) } \\
\text { Recalled: Progress Reduction } \\
\text { Corruption }\end{array}$ & $\begin{array}{l}1=\text { No progress at all } \\
2=\text { little } \\
3=\text { Some } \\
4=\text { Much }\end{array}$ & \\
\hline & $\begin{array}{l}\text { Have you or someone in your } \\
\text { family known of a corruption act? } \\
\text { Recalled: Corrupt act known }\end{array}$ & $\begin{array}{l}1=\mathrm{Yes} \\
2=\mathrm{No}\end{array}$ & \\
\hline & $\begin{array}{l}\text { Total Corruption (Composite } \\
\text { Variable) }\end{array}$ & & \\
\hline \multirow[t]{7}{*}{ Control Variables } & Age Summary & $\begin{array}{l}1=16-25 \\
2=26-40 \\
3=41-60 \\
4=61 \text { and more }\end{array}$ & \\
\hline & Education & $\begin{array}{l}1=\text { illiterate } \\
2=\text { incomplete primary } \\
3=\text { complete primary } \\
\text { 4= Incomplete } \\
\text { Secondary, technical } \\
5=\text { Complete } \\
\text { Secondary, technical } \\
6=\text { Incomplete high } \\
7=\text { Complete high }\end{array}$ & \\
\hline & Gender & $\begin{array}{l}0=\text { male } \\
1=\text { Female }\end{array}$ & \\
\hline & Satisfaction with Democracy & $\begin{array}{l}1=\text { Not at all satisfy } \\
2=\text { Not very satisfy } \\
3=\text { Rather satisfied } \\
4=\text { Very satisfy }\end{array}$ & \\
\hline & Interpersonal Trust & $\begin{array}{l}1=\text { You can never be } \\
\text { too careful when } \\
\text { dealing with others } \\
2=\text { You can trust most } \\
\text { of the people }\end{array}$ & \\
\hline & Socioeconomic Status & $\begin{array}{l}1=\text { Very bad } \\
2=\text { Bad } \\
3=\text { Not bad } \\
4=\text { Good } \\
5=\text { Very Good }\end{array}$ & \\
\hline & Employment & $1=$ self employed & \\
\hline
\end{tabular}


Source: Authors' computation from Latinobarómetro Survey 2006-2010.

$2=$ Employee public
company
$3=$ Employee private
company
$4=$ Student

Table 2-Distribution of trust levels in the different type of institutions

\begin{tabular}{|c|c|c|c|}
\hline \multicolumn{4}{|c|}{ Trust in Government } \\
\hline & $\mathrm{N}$ & $\%$ & Cumulative \% \\
\hline No confidence at all & 22952 & 22.7 & 23.0 \\
\hline Little confidence & 33366 & 33.0 & 56.4 \\
\hline Some confidence & 29985 & 29.7 & 86.4 \\
\hline A lot of confidence & 13617 & 13.5 & 100.0 \\
\hline \multicolumn{4}{|c|}{ Trust in Police } \\
\hline No confidence at all & 27127 & 26.8 & 27.2 \\
\hline Little confidence & 35811 & 35.4 & 63.1 \\
\hline Some confidence & 28508 & 28.2 & 91.7 \\
\hline A lot of confidence & 8269 & 8.2 & 100.0 \\
\hline \multicolumn{4}{|c|}{ Trust in Congress } \\
\hline No confidence at all & 29448 & 29.1 & 30.4 \\
\hline Little confidence & 35878 & 35.5 & 67.5 \\
\hline Some confidence & 24936 & 24.7 & 93.2 \\
\hline A lot of confidence & 6553 & 6.5 & 100.0 \\
\hline \multicolumn{4}{|c|}{ Trust in Judiciary } \\
\hline No confidence at all & 27690 & 27.4 & 28.5 \\
\hline Little confidence & 37820 & 37.4 & 67.4 \\
\hline Some confidence & 25441 & 25.2 & 93.6 \\
\hline A lot of confidence & 6216 & 6.2 & 100.0 \\
\hline \multicolumn{4}{|c|}{ Trust in Political Parties } \\
\hline No confidence at all & 40295 & 39.9 & 40.9 \\
\hline Little confidence & 36152 & 35.8 & 77.6 \\
\hline Some confidence & 18628 & 18.4 & 96.5 \\
\hline A lot of confidence & 3432 & 3.4 & 100.0 \\
\hline \multicolumn{4}{|c|}{ Mean Trust Levels } \\
\hline & Mean & $\begin{array}{l}\text { Standard } \\
\text { Deviation }\end{array}$ & Range \\
\hline & 2.11 & 0.68 & 3.00 \\
\hline
\end{tabular}

Source: Authors' computation from Latinobarómetro Survey 2006-2010. 
Table 3 - Sample Corruption Variables

\begin{tabular}{l|l|l|l}
\hline \multicolumn{5}{c}{ Progress Reduction Corruption (2 Years) } \\
\hline No progress at all & N & $\%$ & Cumulative \% \\
\hline Little progress & 26406 & 26.1 & 27.2 \\
\hline Some progress & 32511 & 32.2 & 60.7 \\
\hline Much progress & 29697 & 29.4 & 91.2 \\
\hline
\end{tabular}

Source: Authors' computation from Latinobarómetro Survey 2006-2010.

Table 4 - Social demographic and other baseline characteristics of the sample

\begin{tabular}{|c|c|c|c|}
\hline \multicolumn{4}{|c|}{ Satisfaction with Democracy } \\
\hline & $\mathrm{N}$ & $\%$ & Cumulative $\%$ \\
\hline Not at all satisfied & 16293 & 16.1 & 16.9 \\
\hline Not very satisfied & 40158 & 39.7 & 58.4 \\
\hline Rather satisfied & 30281 & 30.0 & 89.7 \\
\hline Very satisfied & 9948 & 9.8 & 100.0 \\
\hline \multicolumn{4}{|c|}{ Social Trust } \\
\hline $\begin{array}{l}\text { You can never be too careful } \\
\text { when dealing with others }\end{array}$ & 77674 & 76.9 & 78.9 \\
\hline $\begin{array}{l}\text { You can trust most of the } \\
\text { people }\end{array}$ & 20326 & 20.1 & 99.6 \\
\hline \multicolumn{4}{|c|}{ Age Summary } \\
\hline $16-25$ & 24258 & 24.0 & 24.0 \\
\hline $26-40$ & 34625 & 34.3 & 58.3 \\
\hline $41-60$ & 28442 & 28.1 & 86.4 \\
\hline 61 and more & 13730 & 13.6 & 100.0 \\
\hline \multicolumn{4}{|c|}{ Gender } \\
\hline Male & 48920 & 48.4 & 48.4 \\
\hline Female & 52135 & 51.6 & 100.0 \\
\hline \multicolumn{4}{|c|}{ Self Employed } \\
\hline No & 31652 & 31.3 & 49.1 \\
\hline Yes & 32855 & 32.5 & 100.0 \\
\hline \multicolumn{4}{|c|}{ Public Company Employee } \\
\hline No & 57049 & 56.5 & 88.4 \\
\hline Yes & 7458 & 7.4 & 100.0 \\
\hline \multicolumn{4}{|c|}{ Private Company Employee } \\
\hline No & 46553 & 46.1 & 72.2 \\
\hline Yes & 17954 & 17.8 & 100.0 \\
\hline \multicolumn{4}{|c|}{ Student } \\
\hline No & 58267 & 57.7 & 90.3 \\
\hline
\end{tabular}




\begin{tabular}{|c|c|c|c|}
\hline Yes & 6240 & 6.2 & 100.0 \\
\hline \multicolumn{4}{|c|}{ Education } \\
\hline Illiterate & 10220 & 10.1 & 10.1 \\
\hline Incomplete primary & 21244 & 21.0 & 31.1 \\
\hline Complete primary & 16893 & 16.7 & 47.9 \\
\hline $\begin{array}{l}\text { Incomplete Secondary, } \\
\text { Technical }\end{array}$ & 16445 & 16.3 & 64.1 \\
\hline Complete Secondary, Technical & 20032 & 19.8 & 83.9 \\
\hline Incomplete High & 8338 & 8.3 & 92.2 \\
\hline Complete High & 7883 & 7.8 & 100.0 \\
\hline \multicolumn{4}{|c|}{ Socioeconomic Level } \\
\hline Very bad & 2911 & 2.9 & 2.9 \\
\hline Bad & 14335 & 14.2 & 17.1 \\
\hline Not bad & 43667 & 43.2 & 60.3 \\
\hline Good & 32535 & 32.2 & 92.5 \\
\hline Very Good & 7607 & 7.5 & 100.0 \\
\hline
\end{tabular}

Source: Authors' computation from Latinobarómetro Survey 2006-2010.

\section{Empirical results}

In this section we present our empirical analysis.

Before conducting our regression analysis, the five composite items of institutional trust have been tested with respect to their internal consistency using Cronbach's Alpha. A Cronbach's Alpha in this instance of about 0.80 shows strong internal consistency among these variables. Furthermore, the result suggested that the Cronbach's Alpha would not improve upon removal of any of the variables. Given their high internal consistency a mean confidence score was calculated using information from all five variables.

We proceed, then, by conducting a series of linear regressions using Ordinary Least Square estimations.

Table 5 shows our ordinary least square estimations where institutional trust is a function of corruption presented in a "horse race" regression including the extensive set of covariates and sociodemographic characteristics. Model 1 represent our baseline model where the dependent variable corresponds to our composite variable of institutional trust. The results of model 1 show that institutional trust increases among individuals perceiving a progression in the reduction of corruption. As the respondent to the survey perceives an improvement in the reduction of corruption by 1unit, institutional trust increases by 0.188 . This correlation is statistically significant at $1 \%$ 
level of statistical significance This seems to be consistent also to the inclusion of a series of covariates.

We proceed with an additional robustness check. We disentangle the institutional trust indicator and we replicate our ordinary least square estimations for each institutional trust item separately. This is because the composite indicator might ignore substitutive and complementary relationships between the single components (Model 2-6). Additionally, institutions directly involved in the respect of the law and order and prosecution of corrupt acts might have a higher weight. Model 2-6 show that the relationship between corruption and the single institutional trust item remains unaltered. Trust in government has the highest coefficient. This suggests that the government would gain more trust than the other institutions considered here from a perceived reduction of corruption.

This negative association between perception of corruption and institutional trust recalls the institutional approach mentioned in Section 2. The perception of corruption relates to the citizens evaluation of the correct functioning of the public institutions. This reflects their perception that public official and administrators operates with impartiality and integrity prioritizing the public interests to the personal gain (WANG et al., 2007). This relationship has been found consistent in other geopolitical contexts both at individual-level indicator (HABIBOV, AFANDI e CHEUNG, 2017; MCALLISTER, 2014) as well as society-level indicator (VAN DER MEER, 2010; HAKHVERDIAN and MAYNE, 2012; VAN DER MEER and HAKHVERDIAN, 2017; DONG and KÜBLER, 2018).

Our estimations seem also to confirm aspects of the cultural theory as institutional trust increases with social trust. This means that individuals that trust people in general, tend to trust more public institutions. This positive association seems to be consistent across the different single institutional trust items. 
Table 5 - Ordinary Least Square Estimations

\begin{tabular}{l|l|l|l|l|l|l}
\hline Model 1 & $\begin{array}{c}\text { Institutional } \\
\text { Trust } \\
\text { Model 2 } \\
\text { Government }\end{array}$ & $\begin{array}{c}\text { Trust } \\
\text { Police } \\
\text { Model 3 }\end{array}$ & $\begin{array}{c}\text { Trust } \\
\text { Political } \\
\text { Parties } \\
\text { Model 4 }\end{array}$ & $\begin{array}{c}\text { Trust } \\
\text { Congress } \\
\text { Model 5 }\end{array}$ & $\begin{array}{c}\text { Trust } \\
\text { Judiciary } \\
\text { Model 6 }\end{array}$ \\
\hline $\begin{array}{l}\text { Reduction } \\
\begin{array}{l}\text { Corruption } \\
(2 \text { Years }\end{array}\end{array}$ & $.188^{* *}$ & $.258^{* *}$ & $.168^{* *}$ & $.147^{* *}$ & $.186^{* *}$ & $.176^{* *}$ \\
\hline $\begin{array}{l}\text { Satisfaction with } \\
\text { Democracy }\end{array}$ & $.246^{* *}$ & $.342^{* *}$ & $.172^{* *}$ & $.208^{* *}$ & $.272^{* *}$ & $.231^{* *}$ \\
\hline Social Trust & $.065^{* *}$ & $.059^{* *}$ & $.031^{* *}$ & $.092^{* *}$ & $.075^{* *}$ & $.050^{* *}$ \\
\hline Age Summary & $.011^{* *}$ & $.055^{* *}$ & $.020^{* *}$ & .002 & .003 & $-.022^{* *}$ \\
\hline Gender & $-.015^{* *}$ & $-.047^{* *}$ & $-.038^{* *}$ & $-.015^{*}$ & -.003 & .010 \\
\hline $\begin{array}{l}\text { Public Company } \\
\text { Employee }\end{array}$ & $.081^{* *}$ & $.068^{* *}$ & $.076^{* *}$ & $.068^{* *}$ & $.077^{* *}$ & $.110^{* *}$ \\
\hline $\begin{array}{l}\text { Private Company } \\
\text { Employee }\end{array}$ & $.030^{* *}$ & $.022^{*}$ & $.041^{* *}$ & .010 & $.029^{* *}$ & $.041^{* *}$ \\
\hline Student & $.078^{* *}$ & $0.46^{* *}$ & $.110^{* *}$ & $.053^{* *}$ & $.094^{* *}$ & $.103^{* *}$ \\
\hline Education & $-.007^{* *}$ & $.007^{* *}$ & .001 & $-.014^{* *}$ & $-.013^{* *}$ & $-.015^{* *}$ \\
\hline Socioeconomic Level & $.030^{* *}$ & $.019^{* *}$ & $.026^{* *}$ & $.018^{* *}$ & $.033^{* *}$ & $.055^{* *}$ \\
\hline Level of statistical & & & & &
\end{tabular}

Level of statistical significance ${ }^{* *} \mathrm{p}<0.001{ }^{*} \mathrm{p}<0.05$

Source: Authors' computation on data from Latinobarómetro Survey 2006-2010.

Aligned with previous works, satisfaction with democracy is a positive and significant predictor of institutional trust (HACKVERDIAN and MAYNE, 2012). Our estimations also suggest a negative and statistically significant association between education and institutional trust. This is in line with Seligson (2002) and Chang and Chu (2006). Individuals with a higher level of education are more aware of institutional failures and more critical of the political system.

Similarly, gender results to be negatively and statistically significantly associated with citizens' trust in institutions. Chang and Chu (2006) explain that, for instance in the context of Asian democracies, this might be the result of the "politically marginalization" of women. Although this is more mitigated in Latin America, women in our analysis show less trust in institutions than men.

\section{Conclusions}

The pervasive effects of corruption have affected Latin America for decades. As a region, Latin America has also undergone democratic transitions and reforms 
throughout the twentieth century. This work has analysed the potential affect that the high level of perceived corruption could have on citizen trust in political institutions.

Our results show that in all the functional form specifications institutional trust is positively and statistically significantly associated to individuals' perception of an improvement in reducing corruption. This outcome is valid and consistent to the inclusion of a diversified battery of covariates.

Our estimations also suggest that social trust is positively associated to institutional trust as the cultural theory approach predicts.

Interestingly, when we consider the trust items individually, data shows that political parties are the least trusted institution across Latin America. This could be due to the reported lack of available time and opportunity for new political parties to develop (LLANOS and SAMPLE, 2008). This result is of significant interest since political parties are the main channel between citizens and their representatives. Distrust has been shown to cause voters' apathy (SELIGSON, 2002) as it takes time to re-gain trust once lost it (EASTON, 1965; GAMSON, 1968). The fact that political parties were the least trusted institution, therefore, generates serious challenges for future politicians in this region.

That being said, Chile provides an exception to the general rule in Latin America. Through years Chile has been scoring to be a 'very clean' country by the Perception of Corruption Index. Accordingly, in this research Chile reported the highest confidence in public institutions as well as the higher percentage of confidence in the police.

Our analysis is not immune of limitations.

One of the main constraints of this study, common in all studies in this matter, is the measure of corruption. The secrecy surrounding corruption makes it difficult to estimate internal and external validity. Very rightly, Bohn (2013) stresses the importance of distinguishing between the perception of corruption and the actual exposure to it. This is because the perception of corruption might be far more widespread than what in reality is (SELIGSON, 2002). Seligson (2002), for instance, measures corruption by the personal experience with corruption or victimization. Though, this is still not a perfect way to capture the total effect of corruption as it might seize the regular or petty corruption but not the grand corruption for example (SELIGSON, 2002). Within the perspective of the state-citizens relationship, we claim, though, that social and individual preferences are consistently affected by cognitive aspects such as individuals' perception and believe about rent-seeking 
behaviour and functioning of public institutions. In this respect, citizens' perception of corruption needs to be considered as a key benchmark from policy makers and administrator that are willing to consolidate this state-citizens relationship in a more sustainable way.

It is important to mention that perception of corruption as well as trust towards public institutions are influenced by the media and how they report the news (CHANG and CHU, 2006). Indeed, as Seligson (2002) suggests, in Latin America, state control over the media and unethical behaviour of political leaders might contribute to a focus on 'state scandals' and alter the citizens' trust in institutions. Exploring more the role of the media might help to explain the unexplained variation detected in our empirical analysis.

We would like to stress on the fact that our Ordinary Least Square estimations suggest correlation as they cannot claim a causal mechanism between institutional trust and corruption. Additionally, we are also aware that this empirical approach might encounter problems of endogeneity and reverse causality. Still, on the positive side, we find that the correlation between corruption and institutional trust is statistically significant and follows the same sign even when we include different covariates such as social trust, satisfaction with democracy and a large battery of socio-economic and demographic characteristics. This relationship remains consistently unaltered also when we conduct our estimation for each individual trust item separately.

In view of our results, we recognise that this work opens up windows for further research and investigations.

An interesting line of research concerns gender and trust. Our analysis suggests that women tend to trust less than men public institutions. In view of a more inclusive and sustainable democratic society, shedding light on the inter-connection between women and institutional trust would help designing more effective policies as well as more comprehensive political strategies. Similarly, our results suggest that institutional trust increases with age, lacking among youth and young generations. This is something that ruling elites should not underestimate as it could potentially foster discouragement against "fight[ing] corruption" (MORRIS and KLESNER, 2010). The problem of distrust and scepticism is important for democracies to consider (CLEARLY and STOKES, 2006; NORRIS, 1999). Future generations might become increasingly tolerant to corruption (MORENO, 2002). Therefore, there is a need for political parties to work to change their image and act as reliable representatives in the 
best interest of the electorate, and not in the interest of small elite groups. Replacing the "expectation of corruption" with the "expectation of political representation and accountability" could help to convert voter apathy and increase political interest in younger citizens.

Finally, and very importantly, from a theoretical perspective, our analysis connects with the literature on quality of government institutions (CHANG and CHU, 2006; CHARRON, DIJKSTRA and LAPUENTE, 2015; ROTHSTEIN and TEORELL, 2008). This literature mainly focuses on European and Asian contexts. Our explorative work suggests that Latina America might likely represent the next frontier in this complex debate.

- Luca Andriani é Professor da Escola de Negócios, Economia e Informática, Birkbeck University of London. E-mail: luca.andriani@bbk.ac.uk.

Margarita Maria Escudero Loaiza é Professora Departameto de Gestão, Birkbeck University of London. E-mail: margarita_escudero@icloud.com.

\section{Referências}

ANDERSON, Christopher J.; TVERDOVA, Yuliya V. Corruption, Political Allegiances, and Attitudes Toward Government in Contemporary Democracies. American Journal of Political Science, v. 47, n. 1, p. 91-109, 2003.

BARDHAN, Pranab. Corruption and development: A review of issues. Journal of Economic Literature, v. 35, p. 1320-1346, 1997.

BLIND, Peri K. Building trust in government in the twenty-first century: Review of literature and emerging issues. In: GLOBAL FORUM ON REINVENTING GOVERNMENT BUILDING TRUST IN GOVERNMENT, 7., 2007. 7th Global Forum on Reinventing Government Building Trust in Government. 2007. p. 26-29.

BOHN, Simone R. Corruption in Latin America: Understanding the Perception-Exposure Gap. Journal of Politics in Latin America, v. 4, n. 3, p. 67-95, 2013.

BREHM, John; RAHN, Wendy. Individual-level evidence for the causes and consequences of social capital. American journal of political science, v. 41, n. 3, p. 999-1023, 1997. 
BRIERLEY, John E. C.; DAVID, René. Major legal systems in the world today an introduction to the comparative study of law. 3rd ed. London: Stevens, 1985.

CANACHE, Damarys; ALLISON, Michael E. Perceptions of Political Corruption in Latin American Democracies. Latin American Politics \& Society, v. 47, n. 3, p. 91-111, 2005.

CHANG, Eric C. C.; CHU, Yun-han. Corruption and Trust: Exceptionalism in Asian Democracies? Journal of Politics, v. 68, n. 2, p. 259-271, 2006.

CHANLEY, Virginia A.; RUDOLPH, Thomas J.; RAHN, Wendy M. The origins and consequences of public trust in government: A time series analysis. Public opinion quarterly, v. 64, n. 3, p. 239-256, 2000.

CHARRON, Nicholas; DIJKSTRA, Lewis; LAPUENTE, Victor. Mapping the Regional Divide in Europe: A Measure for Assessing Quality of Government in 206 European Regions. Social Indicators Research, v. 122, n. 2, p. 315-346, 2015.

CHEIBUB, Jose Antonio et al. What Makes Democracy Endure? Journal of Democracy, v. 7, n. 1, p. 39-55, 1996.

CITRIN, Jack; MUSTE, Christopher. Trust in government. In: ROBINSON, J. P.; SHAVER, P. R.; WRIGHTSMAN, L. S. (Eds.). Measures of social psychological attitudes. Academic Press, 1999. v. 2, p. 465-532.

CLEARY, Matthew R.; STOKES, Susan C. Democracy and the Culture of Skepticism: The Politics of Trust in Argentina and Mexico. Russell Sage Foundation, 2006.

CORRALES, Javier; PENFOLD-BECERRA, Michael. Dragon in the Tropics: Hugo Chavez and the Political Economy of Revolution in Venezuela. Brookings Institution Press, 2011.

DALTON, Russell. Democratic Challenges, Democratic Choices. The Erosion of Political Support in Advanced Industrial Democracies. Oxford University Press, 2004.

DALTON, Russell J. Political Support in Advanced Industrial. Oxford University Press, 1999.

DJANKOV, Simeon et al. The Regulation of Entry. Quarterly Journal of Economics, v. 117, n. 1, p. 1-37, 2002.

DOIG, Alan; THEOBALD, Robin (Eds.). Corruption and Democratisation. Routledge, 2000.

DONG, Lisheng; KÜBLER, Daniel. Sources of Local Political Trust in Rural China. Journal of Contemporary China, v. 27, n. 110, p. 1-15, 2018.

EASTON, David. A framework for political analysis. Englewood Cliffs, NJ: Prentice-Hall, 1965. v. 25.

FRIEDMAN, Eric et al. Dodging the grabbing hand: the determinants of unofficial activity in 69 countries. Journal of Public Finance, v. 76, n. 3, p. 459-493, 2000.

FUKUYAMA, Francis. Trust the social virtues and the creation of prosperity. Hamish Hamilton, 1995. GAMSON, William A. Power and discontent. Homewood, IL: Dorsey Press, 1968.

GONZÁLEZ, Luis E. Las crisis políticas de América Latina en los primeros años del siglo. In: ACHARD, Diego; GONZÁlEZ, Luis E. (Eds.). Política y desarrollo en Honduras 2006-2009. Tegucigalpa: PNUD, 2006.

GUPTA, Sanjeev; DAVOODI, Hamid; TIONGSON, Erwin. Corruption and the Provision of Health Care and Education. 2001.

GUPTA, Sanjeev; DE MELLO, Luiz; SHARAN, Raju. Corruption and military spending. European Journal of Political Economy, v. 17, n. 4, p. 749-777, 2001. 
GYIMAH-BREMPONG, Kwabena. Corruption, economic growth, and income inequality in Africa. Economics of Governance, v. 3, n. 3, p. 183-209, 2002.

HABIBOV, Nazim; AFANDI, Elvin; CHEUNG, Alex. Sand or grease? Corruption-institutional trust nexus in post-Soviet countries. Journal of Eurasian Studies, v. 8, n. 2, p. 172-184, 2017.

HAKHVERDIAN, Armen; MAYNE, Quinton. Institutional trust, education, and corruption: A micromacro interactive approach. The Journal of Politics, v. 74, n. 3, p. 739-750, 2012.

HETHERINGTON, Marc J. Why trust matters: Declining political trust and the demise of American liberalism. Princeton University Press, 2005.

HETHERINGTON, Marc J. The political relevance of political trust. American Political Science Review, v. 92, n. 4, p. 791-808, 1998.

HODGSON, Geoffrey; JIANG, Shuxia. The Economics of Corruption and the Corruption of Economics: An Institutionalist Perspective. Journal of Economic Issues, v. 41, n. 4, p. 1043-1061, 2007.

HUNTINGTON, Samuel P. Democracy's Third Wave. The Journal of Democracy, v. 2, n. 2, p. 1234, 1991.

HUNTINGTON, Samuel P. Political order in changing societies. Yale University Press, 1968.

KAASA, Anneli; ANDRIANI, Luca. Determinants of institutional trust: the role of cultural context. Journal of Institutional Economics. 2021 (in press).

KAUFMANN, Daniel; WEI, Shang-Jin. Does "grease money" speed up the wheels of commerce? IMF Working Papers, n. w7093, 2000.

KAUFMAN, Daniel. Corruption: The Facts. Foreign Policy, p. 114-131, 1997.

KLITGAARD, Robert. Controlling Corruption. University of California Press, 1988.

KNACK, Stephen; KEEFER, Philip. Does social capital have an economic payoff? A cross-country investigation. Quarterly Journal of Economics, v. 112, n. 4, p. 1251-1288, 1997.

KURER, Oskar. Corruption: An alternative approach to its definition and measurement. Political Studies, v. 53, n. 1, p. 222-239, 2005.

LAMBSDORFF, Johann G.; CORNELIUS, Peter. Corruption, foreign investment and growth. The Africa competitiveness report, v. 2001, p. 70-78, 2000.

LETKI, Natalia Investigating the Roots of Civic Morality: Trust, Social Capital, and Institutional Performance. Political Behaviour, v. 28, p. 305-325, 2006.

LEVI, Margaret. Social and unsocial capital: A review essay of Robert Putnam's Making Democracy Work. Politics \& Society, v. 24, p. 45-55, 1996.

LEVI, Margaret; STOKER, Laura. Political Trust and Trustworthiness. Annual Review of Political Science, v. 3, p. 475-507, 2000.

LIMA, L. C. The president is not for pardoning. The Economist, Jun. 11, 2013. Available at: <https://www.economist.com/americas-view/2013/06/10/the-president-is-not-for-pardoning>. Accessed on Dec. 09, 2014.

LIPSET, Seymour Martin. The Social Requisite of Democracy Revisited: 1993 Presidential Address. American Sociological Review, v. 59, n. 1, p. 1-22, 1994.

LLANOS, Beatriz; SAMPLE, Kristen. Del dicho al hecho. Manual de buenas prácticas para la participación de mujeres en los partidos políticos latinoamericanos. Lima: International IDEA, 2008. 
MCALLISTER, Ian. Corruption and confidence in Australian political institutions. Australian Journal of Political Science, v. 49, n. 2, p. 174-185, 2014.

MARANGOS, John. What happened to the Washington Consensus? The evolution of international development policy. Journal Of Socio-Economics, v. 38, n. 1, p. 197-208, 2009.

MAURO, Paolo. Corruption and growth. Quarterly Journal of Economics, v. 110, n. 3, p. 681-712, 1995.

MISHLER, William; ROSE, Richard. What Are the Political Consequences of Trust? A Test of Cultural and Institutional Theories in Russia. Comparative Political Studies, v. 38, n. 9, p. 1050-1078, 2005.

MISHLER, William; ROSE, Richard. What are the origins of political trust? Testing institutional and cultural theories in post-communist societies. Comparative Political Studies, v. 34, n. 1, p. 30-62, 2001.

MORENO, Alejandro. Corruption and democracy: A cultural assessment. Comparative Sociology, v. 1, n. 3-4, p. 495-507, 2002.

MORRIS, Stephen D.; KLESNER, Joseph L. Corruption and Trust: Theoretical Considerations and Evidence From Mexico. Comparative Political Studies, v. 43, n. 10, p. 1258-1285, 2010.

NEWTON, Kenneth; NORRIS, Pippa. Confidence in Public Institutions: Faith, Culture, or Performance? In: PHARR, Susan J.; PUTNAM, Robert D. (Eds.). Disaffected Democracies: What's Troubling the Trilateral Countries? Princeton University Press, 2000.

NORRIS, Pippa. Critical Citizens: Global Support for Democratic Government. Oxford England: OUP Oxford, 1999.

NORTH, Douglass C. Institutions. The Journal of Economic Perspectives, v. 5, p. 97-112, 1991.

PERSSON, Anna; ROTHSTEIN, Bo; TEORELL, Jan. Why Anticorruption Reforms Fail-Systemic Corruption as a Collective Action Problem. Governance, v. 26, n. 3, p. 449-471, 2013.

PHARR, Susan J.; PUTNAM, Robert D. Disaffected Democracies: What's Troubling the Trilateral Countries? Princeton University Press, 2000.

PUTNAM, Robert D.; LEONARDI, Robert; NANETTI, Raffella Y. Making democracy work: Civic traditions in modern Italy. Princeton university press, 1993.

RODRIK, Dani. Goodbye Washington Consensus, Hello Washington Confusion? A Review of the World Bank's Economic Growth in the 1990s: Learning from a Decade of Reform. Journal of Economic Literature, v. 44, p. 973-987, 2006.

RODRIK, Dani; SUBRAMANIAN, Arvind; TREBBI, Francesco. Institutions Rule: The Primacy of Institutions Over Geography and Integration in Economic Development. Journal of Economic Growth, v. 9, p. 131-165, 2004.

ROSE-ACKERMAN, Susan. Corruption and government: Causes, consequences, and reform. Cambridge University Press, 1999.

ROTHSTEIN, Bo. Controlling Corruption: The Social Contract Approach. Oxford University Press, 2021.

ROTHSTEIN, Bo; TEORELL, Jan. What is Quality of Government. A theory of Impartial Government Institutions. Governance, v. 21, n. 2, p. 165-190, 2008.

ROTHSTEIN, Bo; STOLLE, Dietlind. How political institutions create and destroy social capital: An institutional theory of generalized trust. In: MEETING OF THE AMERICAN POLITICAL 
SCIENCE ASSOCIATION, 98., 2002, Boston, MA. 98th Meeting of the American Political Science Association. Boston, MA, 2002.

SCHARPF, Fritz W. Governing in Europe: Effective and democratic? Oxford University Press, 1999.

SELIGSON, Mitchell A. The Measurement and impact of corruption Victimization: Survey Evidence from Latin America. World Development, v. 34, n. 2, p. 381-404, 2006.

SELIGSON, Mitchell A. The Impact of Corruption on Regime Legitimacy: A Comparative Study of Four Latin American Countries. Journal of Politics, v. 64, n. 2, p. 408-433, 2002.

TANZI, Vito. Corruption around the world: Causes, consequences, scope, and cures. IMF Working Papers, p. 559-594, 1998.

TANZI, Vito; DAVOODI, Hamid. Corruption, Growth and Public Finances. In: JAIN, Arvind K. (Ed.). The Political Economy of Corruption. New York: Routledge, 2001. p. 89-110.

TANZI, Vito; DAVOODI, Hamid. Corruption, public investment, and growth. In: SHIBATA, Hirofumi et al. (Eds.). The welfare state, public investment, and growth. Tokyo: Springer-verlag, 1998. p. 41-60.

TREISMAN, Daniel. The causes of corruption: a cross-national study. Journal of Public Economics, v. 76, p. 399-457, 2000.

USLANER, Eric M. The moral foundations of trust. Cambridge University Press, 2002.

VAN DE MER, Tom. In what we trust? A multi-level study into trust in parliament as an evaluation of state characteristics. International Review of Administrative Sciences, v. 76, n. 3, p. 517-536, 2010.

VAN DER MEER, Tom; HAKHVERIAN, Armen. Political Trust as the Evaluation of Process and Performance: A Cross-National Study of 42 European Countries. Political Studies, v. 65, n. 1, p. 81$102,2017$.

VEENSTRA, Gerry. Explicating social capital: Trust and participation in the civil space. Canadian Journal of Sociology, v. 27, n. 4, p. 547-572, 2002.

WANG, XiaoHu; WAN WART, Montgomery. When Public Participation in Administration Leads to Trust: An Empirical Assessment of Managers' Perceptions. Public Administration Review, v. 67, n. 2, p. 265-278, 2007.

WANTED: a crusade to purify public life. The Economist, Jun 14, 2001. Available at: <http://www.economist.com/node/656113>. Accessed on: Apr. 05, 2014.

Texto recebido em 31 de março de 2021. Aprovado em 12 de abril de 2021. 